\title{
Contribution of nitrogen mineralization indices, labile organic matter and soil properties in predicting nitrogen mineralization
}

\author{
Juan Manuel Martínez ${ }^{1,2^{*}}$, Juan Alberto Galantini ${ }^{3}$, Matias Ezequiel Duval ${ }^{1,2}$
}

${ }^{I}$ Centro de Recursos Naturales Renovables de la Región Semiárida, Universidad Nacional del Sur (UNS)CONICET, Bahía Blanca, Argentina. ${ }^{2}$ Dpto. Agronomía, Universidad Nacional del Sur (UNS), Bahía Blanca, Argentina. ${ }^{3}$ Comisión de Investigaciones Cientificas (CIC), La Plata, Argentina.

"Corresponding author: jmmartinez@criba.edu.ar.

\begin{abstract}
Abbreviations: $\mathrm{N}$, nitrogen; $\mathrm{N}_{0}$ potentially mineralizable nitrogen; $\mathrm{N}_{0 \mathrm{kf}}$ potentially mineralizable nitrogen determined by a fixed constant rate; $k$; constant rate; SOM, soil organic matter; POM, particulate organic matter; SOC, soil organic carbon; SON, soil organic nitrogen; C:N; carbon-nitrogen ratio of soil; POM-C. total particulate organic carbon; POM-N, total particulate organic nitrogen; $\mathrm{cPOM}-\mathrm{C}$, coarse particulate organic carbon; cPOM-N, coarse particulate organic nitrogen; fPOM-C, fine particulate organic carbon; fPOM-N, fine particulate organic nitrogen; $\mathrm{CH}$, soil carbohydrates; $\mathrm{CHt}$, total carbohydrates; $\mathrm{CHs}$, soluble carbohydrates; gNmin, net $\mathrm{N}$ mineralization; Nan, anaerobic nitrogen; Nhyd, hydrolyzable $\mathrm{N} ; \mathrm{NO}_{3}-\mathrm{N}$, cold nitrate; $\mathrm{N}_{205}, \mathrm{~N}$ determined by spectrometer at $205 \mathrm{~nm} ; \mathrm{N}_{260}, \mathrm{~N}$ determined by spectrometer at $260 \mathrm{~nm}$; Pe, extractable P; BD, soil bulk density; NT, no-tillage system.
\end{abstract}

\begin{abstract}
The objectives of this study were i) to measure the nitrogen $(\mathrm{N})$ mineralization potential; ii) to evaluate $\mathrm{N}$ mineralization indices and labile soil organic matter (SOM) fractions, and iii) to analyze their interrelationship with soil properties for predicting the potential N mineralization in Mollisols under no-tillage of the Argentine Pampas. Potential $\mathrm{N}$ mineralization pool was determined by aerobic incubation of soil samples from $0-20 \mathrm{~cm}$ depth at $25^{\circ} \mathrm{C}$ for six drying and rewetting cycles over 21-24 weeks. The data were fitted to a first-order exponential equation to determine the potentially mineralizable $\mathrm{N}$ at a variable $\left(\mathrm{N}_{0}\right)$ and at a fixed constant rate $\left(\mathrm{N}_{0 \mathrm{kf}}\right)$. Several $\mathrm{N}$ mineralization indices, labile organic fractions and soil properties were determined. A broad range of values were found for $\mathrm{N}_{0}\left(29.9-220.7 \mathrm{mg} \mathrm{kg}^{-1}\right)$ and $\mathrm{N}_{0 \mathrm{kf}}\left(26.9-172.4 \mathrm{mg} \mathrm{kg}^{-1}\right)$. A close relationship $(\mathrm{P}<0.001)$ was found between $\mathrm{N}_{0}$ and $\mathrm{N}_{0 \mathrm{kf}}$ with a high coefficient of determination $\left(\mathrm{R}^{2}=0.94\right)$. High $\mathrm{R}^{2}$ values were found for predicting $\mathrm{N}_{0}$ and $\mathrm{N}_{0 \mathrm{kf}}$ using the principal component as regress variable. Total and labile organic fractions and sand content, explained the majority of the variance. No single $\mathrm{N}$ mineralization index, labile organic fraction or soil property can accurately predict the potential $\mathrm{N}$ mineralization at a variable and at a fixed constant rate. The potential $\mathrm{N}$ mineralization pool may be controlled mainly by the variables related to the size of SOM and some labile fractions, i.e. soil organic $\mathrm{C}(\mathrm{SOC})$ and $\mathrm{N}(\mathrm{SON})$, soluble carbohydrates $(\mathrm{CHs})$ and fine particulate organic N (fPOM-N) in these Mollisols.
\end{abstract}

Keywords: Potentially mineralizable N, Soil organic matter, Principal component analysis, Mollisols 


\section{Introduction}

The Argentinean Pampas region is regarded as one of the most important grain-producing areas worldwide, with wheat (Triticum aestivum L.), maize (Zea mais L.) and soybean (Glycine max L. Merr.) being the main crops (Satorre and Slafer, 1999). Enhancing nitrogen $(\mathrm{N})$-use efficiency is also essential, particularly in semiarid and semihumid areas where fertilizers are rather costly and their efficiency is limited by low water availability. To determine rates of $\mathrm{N}$ fertilizer it is necessary to take into account the inorganic $\mathrm{N}$ in the soil and the organic $\mathrm{N}$ mineralized during the crop growing season (Martínez and Galantini, 2017). In particular, an accurate estimate of the $\mathrm{N}$ mineralized from soil organic matter (SOM) will allow to determine the rate of $\mathrm{N}$ fertilizer to optimize crop yield.

Most estimates of $\mathrm{N}$ supply through mineralization are based on aerobic incubation under controlled conditions over a long period of time (Stanford and Smith, 1972; Martínez and Galantini, 2017). This method is used to determine the soil $\mathrm{N}$ fraction capable of being transformed into mineral forms, also referred to as potentially mineralizable $\mathrm{N}\left(\mathrm{N}_{0}\right)$. This is the labile pool of organic $\mathrm{N}$ considered to be a standardized estimate of potential mineralization in soil (Ros et al., 2011; St. Luce et al., 2011), i.e. it reflects the amount of organic $\mathrm{N}$ that can be mineralized.

A number of chemical and biological methods have long been applied to identify the potential mineralization of soil organic $\mathrm{N}$ in a quick simple way (Martínez and Galantini, 2017). Moreover, laboratories refuse to apply these methods on the grounds that they are rather time-consuming; modern soil testing laboratories, instead, strive for a short turn-around time and faster procedures. Biological indices such as anaerobic incubation are sensitive to different soil managements (Moya et al., 2016; Martínez et al., 2017). Chemical methods are based on the hypothesis that a specific extractant releases $\mathrm{N}$ from a pool, but they do not usually require that the $\mathrm{N}$ pool released by extraction should be chemically homogeneous or biologically significant (St. Luce et al. 2011). Some authors (Gianello and Bremner, 1986) have proposed that soil digestion with a strong salt can be used to estimate soil N-mineralization. But chemical methods cannot simulate the action of microorganisms and they do not account for the effects of environmental conditions (Sharifi et al., 2007).

Soil organic matter and its labile fractions are considered important factors in regulating $\mathrm{N}$-dynamics (Ramírez et al., 2016; Martínez et al., 2017) in view of their key role in $\mathrm{N}$ mineralization and $\mathrm{N}$ availability to crops. Available soil $\mathrm{N}$ is primarily produced by mineralization of SOM (Martínez-Lagos et al., 2015), which supplies 50 to $80 \%$ of the $\mathrm{N}$ needed by the crop (St. Luce et al., 2011). Soil organic N (SON) accounts for as much as $95 \%$ of total $\mathrm{N}$ in the topsoil. This organic fraction enters the soil as particulate organic matter (POM) through aboveground plant litter and root litter (Martínez et al., 2017). The POM may provide more accurate information on $\mathrm{N}$ mineralization as it contains easily mineralizable $\mathrm{N}$ fractions. This fraction represents the mineralizable pool and it can easily predict the $\mathrm{N}$ mineralization capacity (Martínez et al., 2017). Haynes (2005) reported that POM is an important labile $\mathrm{N}$ pool in several soils. However, decomposition of this labile fraction is heavily dependent on residue input and weather conditions (Martínez et al., 2017), which vary significantly between years in semiarid and semihumid areas.

None of the mineralization indices or SOM fractions has been universally accepted as an indicator 
of the soil's capacity to supply $\mathrm{N}$ and substantial uncertainty exists on their role in the N-cycle (Ros et al., 2011). On the other hand, chemical and physical properties could affect the $\mathrm{N}$ mineralization (St. Luce et al., 2011). However, understanding their function and interrelationships with other soil properties in the N-cycle may improve our ability to predict the $\mathrm{N}$ mineralization. For this reason, combining these properties in multiple regression (MR) models, could improve the prediction of $\mathrm{N}$ mineralization in different soils (Schomberg et al., 2009; Ros et al., 2011). An extensive number of studies have related $\mathrm{N}$ mineralization to soil properties and climate conditions (Schomberg et al., 2009). Combining SOM fractions and soil properties into MR models has been shown to improve the prediction of potential $\mathrm{N}$ mineralization (Schomberg et al., 2009; Dessureault-Rompré et al., 2010; Nyiraneza et al., 2011). However, as was mentioned by different authors (Shukla et al., 2004; Ros et al., 2011) using MR could result in multicollinearity between the factors of the model, confusing the biological sense of each variable in the mineralization process. One way to reduce the multicollinearity and see the interrelationship of all variables in different dimensions is using a multivariate statistical analysis as the principal component analysis (PCA). Principal component analysis helps to avoid these problems by grouping highly correlated parameters into principal components (PC). Those PCs can be used as a new set of independent variables for regression analysis (Shukla et al., 2004). Nowadays, there are few relevant studies by linking together $\mathrm{N}$ mineralization indices, labile organic fractions and soil properties by using multivariate analysis. In addition, this statistical analysis combines variables in such a way that the underlying soil factors relevant for predicting the potential $\mathrm{N}$ mineralization might be identified (Ros et al., 2011).
In these soils under no-tillage (NT), POM input by crop residues is highly variable and usually low due to the climatic conditions. On the other hand, regarding the positive effect of POM on nutrient availability; especially, inorganic-N (Galantini and Landriscini, 2007), there is a lack of information about the main factors that regulate the potential $\mathrm{N}$ mineralization when they are all considered together under these conditions. In addition, knowing information about the size and the cycling of this inorganic-N pool is important to develop adequate fertilization strategies (Martínez-Lagos et al., 2015).

Our hypothesis is that understanding the interrelationships among the labile SOM fractions, $\mathrm{N}$ mineralization indices and soil properties could enable the identification of the main factors affecting the size and kinetics of the mineralizable $\mathrm{N}$ pool. The objectives of this study were i) to measure the $\mathrm{N}$ mineralization potential; ii) to evaluate mineralization indices and labile organic matter fractions, and iii) to analyze their interrelationship with soil properties for predicting the potential $\mathrm{N}$ mineralization in Mollisols under NT of the Argentine Pampas. In this study, PCA coupled with MR was used with a set of $\mathrm{N}$ mineralization indices, labile organic fractions, and chemical and physical properties that better explain the variations in the potential $\mathrm{N}$ mineralization.

\section{Materials and Methods}

\subsection{Experimental sites}

In 2010, 2011 and 2012, composite soil samples (fifteen to twelve soil cylinders) were collected from nine fields under NT. The sites were located in the southwest of the Argentinian Pampas (Figure 1). Predominant soils were Mollisolls (Soil Survey Staff, 2010) developed on aeolian sediments (loess), 
with a wide range of depth fluctuation, texture, soil organic carbon (SOC) content and fertility (Álvarez and Lavado, 1998). In semiarid and semihumid re- gions, soils are characterized by a low SOM content, and its dynamics is more strongly affected by water availability (Galantini et al., 2016).

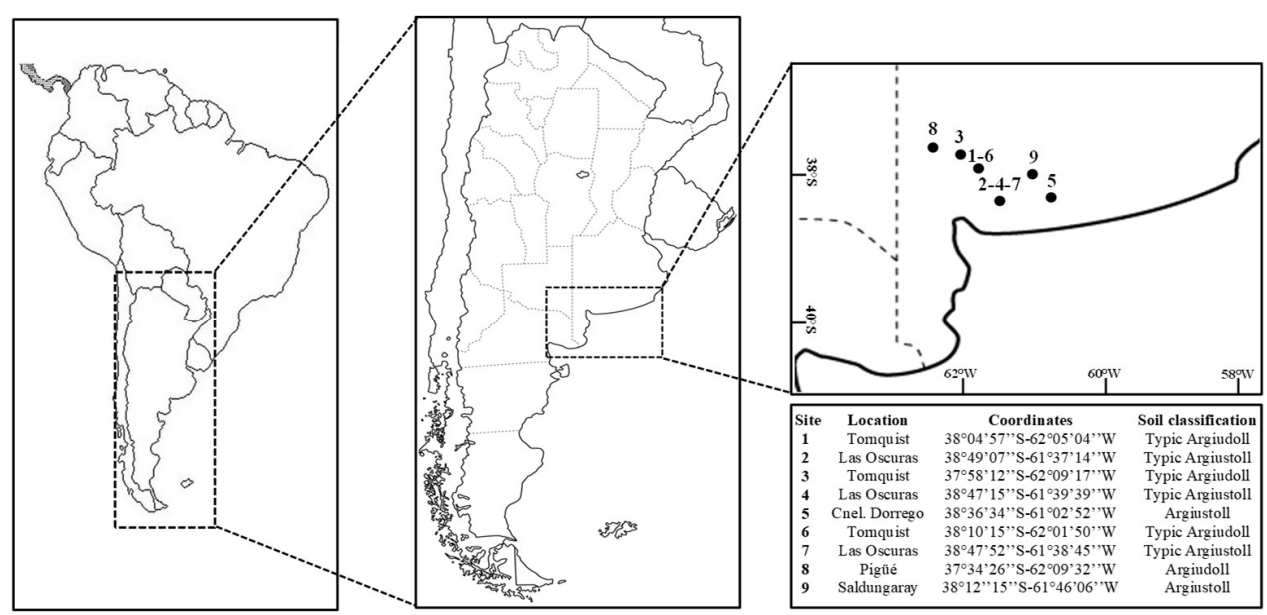

Figure 1. Location of sites in the southwest of the Argentine Pampas.

A composite soil sample (16 and 20 soil cylinders) was collected from $\mathrm{N}$ fertilization trials in wheat in the non-fertilized plots before crop seeding at 0-20 cm depth. This sampling depth was selected, because Molisolls have a mollic epipedon or a surface horizon of $18 \mathrm{~cm}$ depth (Soil Survey Staff, 2010). The experimental design included three completely randomized blocks. Soil and climate characteristics are shown in Table 1. The rainfall gradient determines an udic (semihumid) soil moisture regime for continental sites $(1,3,6,8$ and 9) and ustic (semiarid) for sites next to the coast
(2, 4, 5 and 7). Rainfall amount and frequency are irregular across all sites, the rainiest seasons being autumn (March-April) and spring (SeptemberOctober). All soils had been under continuous agriculture for 10-15 years under NT. The NT system was characterized by the absence of tillage with over $30 \%$ residues covering the soil surface in all sites. In general, herbicide (1-2 $\mathrm{L} \mathrm{ha}^{-1}$ of glyphosate) was applied for weed control and for initiating the chemical fallow. Data on annual mean temperature and precipitation was collected from SMN (National Weather Service) weather stations. 
Table 1. Soil and climate characteristics of sites.

\begin{tabular}{|c|c|c|c|c|c|c|}
\hline \multirow[b]{2}{*}{ Sites } & \multirow[b]{2}{*}{ Year } & \multirow[b]{2}{*}{ Location } & \multirow{2}{*}{$\begin{array}{c}\text { Previous } \\
\text { crops }\end{array}$} & \multirow[b]{2}{*}{ Soil classification ${ }^{\mathrm{a}}$} & \multirow{2}{*}{$\frac{\text { MAT }^{b}}{\left({ }^{\circ} \mathrm{C}\right)}$} & \multirow{2}{*}{$\frac{\mathrm{RA}^{\mathrm{c}}}{(\mathrm{mm})}$} \\
\hline & & & & & & \\
\hline 1 & 2010 & $\begin{array}{l}38^{\circ} 04^{\prime} 57^{\prime \prime} \mathrm{S} \\
62^{\circ} 05^{\prime} 04^{\prime \prime} \mathrm{W}\end{array}$ & Wheat & Typic Argiudoll & 14.5 & 695 \\
\hline 2 & 2010 & $\begin{array}{l}38^{\circ} 49^{\prime} 07^{\prime \prime} \mathrm{S} \\
61^{\circ} 37^{\prime} 14^{\prime \prime} \mathrm{W}\end{array}$ & Wheat & Typic Argiustoll & 15.0 & 533 \\
\hline 3 & 2010 & $\begin{array}{l}37^{\circ} 58^{\prime} 12^{\prime \prime} \mathrm{S} \\
62^{\circ} 09^{\prime} 17^{\prime \prime} \mathrm{W}\end{array}$ & Barley & Typic Argiudoll & 14.3 & 550 \\
\hline 4 & 2011 & $\begin{array}{l}38^{\circ} 47^{\prime} 15^{\prime \prime} \mathrm{S} \\
61^{\circ} 39^{\prime} 39^{\prime \prime} \mathrm{W}\end{array}$ & Wheat & Typic Argiustoll & 15.0 & 470 \\
\hline 5 & 2011 & $\begin{array}{l}38^{\circ} 36^{\prime} 34^{\prime \prime} \mathrm{S} \\
61^{\circ} 02^{\prime} 52^{\prime \prime} \mathrm{W}\end{array}$ & Barley & Argiustoll & 14.7 & 648 \\
\hline 6 & 2011 & $\begin{array}{l}38^{\circ} 10^{\prime} 15^{\prime \prime} \mathrm{S} \\
62^{\circ} 01^{\prime} 50^{\prime \prime} \mathrm{W}\end{array}$ & Sunflower & Typic Argiudoll & 14.5 & 777 \\
\hline 7 & 2012 & $\begin{array}{l}38^{\circ} 47^{\prime} 52^{\prime \prime} \mathrm{S} \\
61^{\circ} 38^{\prime} 45^{\prime \prime} \mathrm{W}\end{array}$ & Wheat & Typic Argiustoll & 15.0 & 624 \\
\hline 8 & 2012 & $\begin{array}{l}37^{\circ} 34^{\prime} 26^{\prime \prime} \mathrm{S} \\
62^{\circ} 09^{\prime} 32^{\prime \prime} \mathrm{W}\end{array}$ & Soybean & Argiudoll & 13.8 & 1045 \\
\hline 9 & 2012 & $\begin{array}{l}38^{\circ} 12^{\prime \prime} 15^{\prime \prime} \mathrm{S} \\
61^{\circ} 46^{\prime} 06^{\prime \prime} \mathrm{W}\end{array}$ & Wheat & Argiustoll & 14.7 & 694 \\
\hline
\end{tabular}

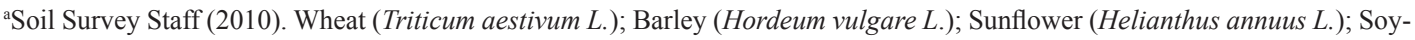
bean (Glycine Max L. Merr.). ${ }^{b}$ MAT, mean annual temperature. ${ }^{~} \mathrm{RA}$, annual rainfall in the sampled year (mm).

\subsection{Chemical and physical analyses}

The soil samples were air-dried, sieved $(<2 \mathrm{~mm})$ and chemically analyzed for the following parameters: SOC by dry combustion using a Leco $\mathrm{C}$ automatic analyzer (Leco Corporation, St Joseph, MI); soil organic N (SON) by micro-Kjeldahl method (Bremner, 1996); $\mathrm{pH}$ in a soil-water suspension of 1:2.5; Bray-
I extractable P (Pe) (Bray and Kurtz, 1945). Particle size distribution was determined by the pipette method (Gee and Bauder, 1986). Also, undisturbed soil samples were taken to the $0-5,5-10,10-15$ and $15-20$ $\mathrm{cm}$ depths by core cylinders $5 \mathrm{~cm}$ in height and $4.7 \mathrm{~cm}$ in diameter to calculate bulk density (BD) (Blake and Hartge, 1986). The analytical data of the sampled sites are summarized in Table 2.

Table 2. Chemical and physical soil properties at the $0-20 \mathrm{~cm}$ depth.

\begin{tabular}{|c|c|c|c|c|c|c|c|c|c|}
\hline \multirow[b]{3}{*}{ Sites } & & & \multirow{3}{*}{$\frac{\mathrm{Pe}}{\left(\mathrm{mg} \mathrm{kg}^{-1}\right)}$} & \multirow{3}{*}{$\mathrm{pH}$} & \multirow{3}{*}{$\mathrm{C}: \mathrm{N}$} & & \multicolumn{3}{|c|}{ Texture } \\
\hline & SOC & SON & & & & BD & sand & silt & clay \\
\hline & \multicolumn{2}{|c|}{$\left(\mathrm{g} \mathrm{kg}^{-1}\right)$} & & & & $\left(\mathrm{Mg} \mathrm{m}^{-3}\right)$ & & $\left.\mathrm{g} \mathrm{kg}^{-1}\right)$ & \\
\hline 1 & 22 & 1.4 & 20 & 7.0 & 10 & 1.15 & 414 & 380 & 206 \\
\hline 2 & 15 & 1.3 & 26 & 7.4 & 11 & 1.26 & 567 & 399 & 34 \\
\hline 3 & 19 & 1.1 & 15 & 6.7 & 12 & 1.18 & 368 & 404 & 228 \\
\hline 4 & 13 & 1.2 & 19 & 6.2 & 11 & 1.27 & 751 & 154 & 95 \\
\hline 5 & 20 & 1.5 & 22 & 6.2 & 11 & 1.25 & 466 & 321 & 214 \\
\hline 6 & 18 & 1.4 & 14 & 6.4 & 10 & 1.18 & 541 & 284 & 176 \\
\hline 7 & 16 & 1.2 & 26 & 6.0 & 12 & 1.31 & 615 & 177 & 208 \\
\hline 8 & 31 & 2.6 & 10 & 7.6 & 13 & 1.13 & 254 & 538 & 208 \\
\hline 9 & 15 & 1.3 & 10 & 6.3 & 12 & 1.32 & 510 & 266 & 225 \\
\hline
\end{tabular}

SOC, soil organic carbon $\left(\mathrm{g} \mathrm{kg}^{-1}\right)$; $\mathrm{SON}$, total soil $\mathrm{N}\left(\mathrm{g} \mathrm{kg}^{-1}\right)$; Pe, extractable $\mathrm{P}\left(\mathrm{mg} \mathrm{kg}^{-1}\right) ; \mathrm{C}: \mathrm{N}$, carbon: nitrogen ratio of soil; $\mathrm{BD}$, soil bulk density $\left(\mathrm{Mg} \mathrm{m}^{-3}\right)$. 


\subsection{Long-term aerobic incubation}

The samples were subjected to an aerobic long-term incubation following the procedure by Griffin et al. (2008). Briefly, $250 \mathrm{~g}$ of air-dried soil was sieved to 2 $\mathrm{mm}$ and placed in $1 \mathrm{~L}$ glass jars; two $5 \mathrm{~mm}$ diameter holes were drilled into each jar lid to facilitate the aerobic exchange. Distilled water was added to the soil in order to bring their moisture content to $60 \%$ of their water-holding capacity (Klute, 1986) and incubated for six drying-rewetting cycles at $25^{\circ} \mathrm{C}$. An optimal temperature between 25 and $35^{\circ} \mathrm{C}$ was determined to study the potential $\mathrm{N}$ mineralization, whereas other authors (Griffin et al., 2008; Dessureault-Rompré et al., 2010) concluded that microbial activity was highest at $60 \%$ of water-holding capacity and lowest under $30 \%$. Three replicates and a reference sample for controlling soil water content were incubated. Soil water content was measured daily; when it reached $30 \%$, it was rewetted to $60 \%$ of water-holding capacity, and another drying-rewetting cycle began. After rewetting, the soils in the jars were sampled with a single $15 \mathrm{~mm}$ diameter core for each jar to determine soil inorganic $\mathrm{N}\left(\mathrm{NO}_{3}^{-}-\mathrm{N}\right.$ plus $\left.\mathrm{NH}_{4}^{+}-\mathrm{N}\right)$ by steam distillation (Mulvaney, 1996). Following incubation, potential $\mathrm{N}$ mineralization was determined by non-linear regression (equation 1), assuming that the cumulative mineralized $\mathrm{N}$ (Nmin) fitted with an exponentially first-order kinetic model (Stanford and Smith, 1972):

$$
N \min =N_{0}\left(1-e^{-k t}\right)
$$

where: Nmin is the cumulative amount of $\mathrm{N}$ mineralized at time $\mathrm{t}, \mathrm{N}_{0}$ is the potentially mineralizable $\mathrm{N}$, and $k$ is the rate constant.

The $\mathrm{N}$ mineralized in the first two weeks was not used in the curve fitting model because it represented the initial flow of mineralization on rewetting (Nyiraneza et al., 2011) or net mineralization (Ros et al., 2011).
Coarse-textured and fine-textured soils were incubated for 21 and 27 weeks, respectively. Sharifi et al. (2007) suggested that incubations should take at least 24 weeks to obtain reliable values of potential $\mathrm{N}$ mineralization.

A fixed $k$ value $\left(0.054\right.$ week $\left.^{-1}\right)$ was used in the single exponential model (equation 1) to determine $\mathrm{N}_{0 \mathrm{kf}}$, as proposed by Sharifi et al. (2007). Potentially mineralizable $\mathrm{N}$ with a fixed constant rate was determined with the same model (equation 1) fitting procedures as $\mathrm{N}_{0}$. These authors assumed an average $k$ value determined by Stanford and Smith (1972) for 39 soils, to eliminate the effects of the colinearity of parameters when simultaneously fitting $\mathrm{N}_{0}$ and $k$.

\subsection{Labile soil organic matter fractions}

2.4.1. Particle size fractionation of soil organic matter

The physical fractionation of SOM was performed by wet sieving (Duval et al., 2013). Briefly, $50 \mathrm{~g}$ of soil previously air-dried and sieved was dispersed in 120 $\mathrm{mL}$ glass containers and mixed with $100 \mathrm{~mL}$ of distilled water. Ten glass beads ( $5 \mathrm{~mm}$ in diameter) were added to enhance destruction and reduce potential problems created by different sand contents. After dispersion, the soil suspension was sieved through two connected sieves (105 microns and 53 microns in diameter). The sieves were moved back and forth, and the soil retained in the top sieve was sprinkled with distilled water until the water in the bottom sieve was clear to the naked eye. The fractions obtained were i) a coarse particle size fraction (105-2000 microns) containing coarse sands and coarse POM, and ii) a medium particle size fraction (53-105 microns) containing more stable or fine POM, and fine and very fine sand; the fine particle size fraction ( $<53$ microns) was discarded. Each particle size fraction was analyzed for $\mathrm{C}$ and $\mathrm{N}$, and two fractions were obtained: i) particulate organic 
$\mathrm{C}$ and $\mathrm{N}$ in the coarse particle size fraction (cPOM-C and cPOM-N, respectively) and ii) particulate organic $\mathrm{C}$ and $\mathrm{N}$ in the medium particle size fraction (fPOM-C and $\mathrm{PPOM}-\mathrm{N}$, respectively). Carbon and $\mathrm{N}$ contents in POM were determined using the same methods as for SOC and SON, respectively.

\subsubsection{Total and soluble carbohydrates}

Extraction of carbohydrates was performed employing two different samples. Total carbohydrates $(\mathrm{CHt})$ extraction was performed by an acid hydrolysis as follow: $1 \mathrm{~g}$ of soil sample was treated with $10 \mathrm{~mL}$ $0.5 \mathrm{~mol} \mathrm{~L}^{-1} \mathrm{H}_{2} \mathrm{SO}_{4}$, heated at $80^{\circ} \mathrm{C}$ for $24 \mathrm{~h}$. In the other sample, soluble carbohydrates $(\mathrm{CHs})$ extraction was carried out as follow: $1 \mathrm{~g}$ of soil sample was suspended in $10 \mathrm{~mL}$ of distilled water and heated at $80{ }^{\circ} \mathrm{C}$ for $24 \mathrm{~h}$. After the extraction with hot water, $\mathrm{H}_{2} \mathrm{SO}_{4}$ was added to obtain a $0.5 \mathrm{~mol} \mathrm{~L}^{-1}$ concentration as in the dilute acid hydrolysis procedure, and immediately processed. After extraction by each way, each suspension was centrifuged at $4000 \mathrm{rpm}$ during 15 min (Puget et al., 1999). Carbohydrate contents of the extract were determined by spectrometry using the sulphuric-phenol spectrometric method with glucose as the standard (Dubois et al., 1956).

\subsection{Indices of $N$ mineralization}

\subsubsection{Chemical hydrolyzable nitrogen}

The hydrolyzable $\mathrm{N}$ was chemically extracted by soil digestion with a strong salt solution of $2 \mathrm{~mol} \mathrm{~L}^{-1} \mathrm{KCl}$, as described by Gianello and Bremner (1986). The procedure was performed by digesting $3 \mathrm{~g}$ of soil in $20 \mathrm{~mL}$ of the solution at $100{ }^{\circ} \mathrm{C}$ for 4 hours in a block digester. The sample was then cooled and $\mathrm{NH}_{4}^{+}-\mathrm{N}$ was determined by steam distillation (Mulvaney, 1996). The initial soil $\mathrm{NH}_{4}^{+}-\mathrm{N}$ was extracted at room temper- ature and the hydrolyzable $\mathrm{N}$ (Nhyd) was determined by subtracting the initial $\mathrm{NH}_{4}^{+}-\mathrm{N}$ without digestion.

\subsubsection{Cold nitrate-extraction}

Briefly, $5 \mathrm{~g}$ of air-dried soil was added to $50 \mathrm{~mL}$ of 2 mol L${ }^{-1} \mathrm{KCl}$. The suspension was shaken for $30 \mathrm{~min}$ at $290 \mathrm{rpm}$. The samples were then centrifuged and the extract was filtered. The $\mathrm{NO}_{3}-\mathrm{N}$ concentration was determined by steam distillation (Mulvaney, 1996).

\subsubsection{Determination by UV-visible spectrophotometry}

The procedure was performed according to the method described by MacLean (1964). A $5 \mathrm{~g}$ of soil was added to $100 \mathrm{~mL}$ of $0.01 \mathrm{~mol} \mathrm{~L}^{-1} \mathrm{NaCO}_{3} \mathrm{H}$. The suspension was shaken for $15 \mathrm{~min}$ in a $250 \mathrm{~mL}$ Erlenmeyer flask. The samples were centrifuged and the suspensions were filtered through a Whatman grade 42 filter paper. The ultraviolet absorption at $205\left(\mathrm{~N}_{205}\right)$ and $260\left(\mathrm{~N}_{260}\right) \mathrm{nm}$ was measured with a T60U UVvisible spectrophotometer (PG Instruments). When UV measurements were made at $205 \mathrm{~nm}$, two drops of concentrated $\mathrm{HCl}$ were added to remove carbonate wavelength peaks.

\subsubsection{Anaerobic nitrogen}

Anaerobic N (Nan) was determined following the method by Martínez et al. (2017) in a short-term anaerobic incubation. A $5 \mathrm{~g}$ of soil was put into a test tube and $25 \mathrm{~mL}$ of distilled was added. The tube caps were securely tightened and then the tubes were incubated for 7 days at $40{ }^{\circ} \mathrm{C}$ under anoxic conditions. After incubation, the samples were transferred to a distillation flask and $25 \mathrm{~mL}$ of 4 mol L-1 $\mathrm{KCl}$ was added; the $\mathrm{NH}_{4}^{+}-\mathrm{N}$ was determined by steam distillation (Mulvaney, 1996). The Nan content was estimated by subtracting 
inorganic- $\mathrm{N}$ in the form of $\mathrm{NH}_{4}{ }^{+}-\mathrm{N}$ extracted with $2 \mathrm{~mol} \mathrm{~L}^{-1} \mathrm{KCl}$-at room temperature and without incubation- from the amount obtained in the incubated extract.

\subsubsection{Net $\mathrm{N}$ mineralization}

The net $\mathrm{N}$ mineralization (gNmin) involved pre-incubation of soils using the long-term aerobic method (Sharifi et al., 2007). The air-dried soil was placed in the respective bottle and distilled water was added to $60 \%$ of water-holding capacity; this was followed by incubation at $25^{\circ} \mathrm{C}$ for 12 days. The jars were then sampled with a sampler, and inorganic $\mathrm{N}\left(\mathrm{NO}_{3}^{-}-\mathrm{N}\right.$ plus $\left.\mathrm{NH}_{4}^{+}-\mathrm{N}\right)$ was determined by steam distillation (Mulvaney, 1996).

\subsection{Statistical analysis}

A non-linear regression analysis was used to obtain $\mathrm{N}_{0}, \mathrm{~N}_{0 \mathrm{kf}}$ and $k$ of equation 1. Pearson's correlations were performed between $\mathrm{N}_{0}$ and $\mathrm{N}_{0 \mathrm{kf}}$ with soil $\mathrm{N}$ mineralization indices, labile organic fractions and soil properties to evaluate the relationships between individual variables. A PCA was performed with the significant correlated $(\mathrm{P}<0.05)$ variables for $\mathrm{N}_{0}$ and $\mathrm{N}_{\text {okf }}$. The objective of multivariate analysis was to analyze all the variables correlated together and the relationship among them, and how they affected the potential $\mathrm{N}$ mineralization pool. Also, this analysis was employed as a data-reduction tool to select the most appropriate factors, through which the number of independent variables could be reduced and problems related to multicollinearity could be eliminated (Li et al., 2013). Only PCs with eigenvalues $>1$ were retained for the regression analysis, because they explained the data variability. Within each PC, variables receiving weighted loading values within $10 \%$ of the highest weighted loading were selected for each PC (Li et al., 2013). Multiple regressions were performed using the $\mathrm{PC}>1$ by multivariate analysis for predicting $\mathrm{N}_{0}$ and $\mathrm{N}_{0 \mathrm{kf}}$ (dependent variables) using the stepwise model with a maximum P-value of 0.05 for input and output. The MR model was used to determine the best combination of PC that maximizes the prediction of $\mathrm{N}_{0}$ and $\mathrm{N}_{0 \mathrm{kf}}$. The statistical analysis was carried out with Infostat software (Di Rienzo et al., 2013).

\section{Results}

\subsection{Soil chemical and physical characteristics}

Soil organic $\mathrm{C}$ ranged from $13 \mathrm{~g} \mathrm{~kg}^{-1}$ to $31 \mathrm{~g} \mathrm{~kg}^{-1}$ with a mean value of $19 \mathrm{~g} \mathrm{~kg}^{-1}$ (Table 2). Soil $\mathrm{pH}$ was slightly alkaline to mildly acid with an average of 7.0 and a range between 6.0 and 7.6. Regarding soil texture, sand content in soil was between 254 and $751 \mathrm{~g} \mathrm{~kg}^{-1}$, averaging $498 \mathrm{~g} \mathrm{~kg}^{-1}$. Taking into account the amount of fine fractions (silt plus clay), whose mean values were $502 \mathrm{~g} \mathrm{~kg}^{-1}$, a significant and positive relationship was found between silt plus clay and SOC (data not shown), with a high coefficient of determination $\left(\mathrm{R}^{2}=0.76\right)$

\subsection{Potential $N$ mineralization}

A broad range of values was found for $\mathrm{N}_{0}$ and $\mathrm{N}_{0 \mathrm{k}}$, the highest being 220.7 and $172.4 \mathrm{mg} \mathrm{kg}^{-1}$, and the lowest 29.9 and $26.9 \mathrm{mg} \mathrm{kg}^{-1}$, respectively. The mean value of $k$ across all sites was 0.0329 week $^{-}$ ${ }^{1}$, ranging from 0.0125 to 0.163 week $^{-1}$ (Table 3). The relationship between $\mathrm{N}_{0}$ and $\mathrm{N}_{0 \mathrm{kf}}$ was found to be very close $(\mathrm{y}=1.19 \mathrm{x}+0.97 ; \mathrm{P}<0.001)$ with a high coefficient of determination $\left(\mathrm{R}^{2}=0.94\right)$ (data not shown). 
Table 3. Potentially mineralizable $\mathrm{N}$ in the long term at a variable and at a fixed constant rate, and mineralization constant rates (mean \pm standar deviation) by site.

\begin{tabular}{|c|c|c|c|}
\hline \multirow[b]{2}{*}{ Sites } & $\mathrm{N}_{0}$ & $\mathrm{~N}_{0 \mathrm{kf}}$ & $k$ \\
\hline & \multicolumn{2}{|c|}{$\left(\mathrm{mg} \mathrm{kg}^{-1}\right)$} & $\left(\right.$ week $\left.^{-1}\right)$ \\
\hline 1 & $153.3 \pm 17.9$ & $130.8 \pm 8.6$ & $0.024 \pm 0.006$ \\
\hline 2 & $109.4 \pm 7.9$ & $78.3 \pm 4.4$ & $0.017 \pm 0.004$ \\
\hline 3 & $139.0 \pm 6.7$ & $133.8 \pm 1.2$ & $0.044 \pm 0.015$ \\
\hline 4 & $29.9 \pm 3.4$ & $26.9 \pm 2.9$ & $0.031 \pm 0.006$ \\
\hline 5 & $130.3 \pm 15.1$ & $111.8 \pm 2.3$ & $0.030 \pm 0.011$ \\
\hline 6 & $117.5 \pm 11.2$ & $89.5 \pm 3.6$ & $0.018 \pm 0.005$ \\
\hline 7 & $50.0 \pm 6.4$ & $49.8 \pm 2.7$ & $0.094 \pm 0.065$ \\
\hline 8 & $215.3 \pm 5.0$ & $172.4 \pm 2.8$ & $0.019 \pm 0.001$ \\
\hline 9 & $113.2 \pm 9.4$ & $87.8 \pm 5.0$ & $0.019 \pm 0.003$ \\
\hline mean & 117.5 & 97.9 & 0.033 \\
\hline $\mathrm{SD}^{\mathrm{a}}$ & 53.1 & 43.1 & 0.030 \\
\hline $\mathrm{CV}^{\mathrm{b}}$ & 45 & 44 & 92 \\
\hline
\end{tabular}

$\mathrm{N}_{0}$, aerobic potentially mineralizable $\mathrm{N} ;{ }^{\mathrm{N}}{ }_{0 \mathrm{kP}}$ potentially mineralizable $\mathrm{N}$ at a fixed constant rate $(k)\left(0.054\right.$ week $\left.^{-1}\right)$; k, mineralization constant rate (week $\left.{ }^{-1}\right)$. ${ }^{\text {aSD }}$, standard deviation; ${ }^{\mathrm{b}} \mathrm{CV}$, coefficient of variation.

3.3. Soil N-mineralization indices and soil organic matter fractions

Nitrogen mineralization indices and soil labile organic fractions are shown in Table 4. Regarding biological methods, the mean gNmin value for all sites was $64.2 \mathrm{mg} \mathrm{kg}^{-1}$, ranging from 30.3 to 116.3 $\mathrm{mg} \mathrm{kg}{ }^{-1}$. Nan ranged from 25.2 to $99.4 \mathrm{mg} \mathrm{kg}^{-1}$, whereas, Nhyd ranged from 10.7 to $67.2 \mathrm{mg} \mathrm{kg}^{-1}$. The mean $\mathrm{NO}_{3}-\mathrm{N}$ value was $20.1 \mathrm{mg} \mathrm{kg}^{-1}$, with a range between $11.2 \mathrm{mg} \mathrm{kg}^{-1}$ and $27.5 \mathrm{mg} \mathrm{kg}^{-1}$. The mean UV-absorbance values were 1.84 and 0.44 for $\mathrm{N}_{205}$ and $\mathrm{N}_{260}$, respectively. The $\mathrm{CV}$ between mineralization indices followed the sequence $\mathrm{N}_{260}<$
$\mathrm{N}_{205}<\mathrm{NO}_{3}-\mathrm{N}<\mathrm{gNmin}<\mathrm{Nan}<$ Nhyd, where values ranged from 16 to $40 \%$.

The mean values of labile organic fractions were 1.07; 1.39 ; 0.103 and $0.161 \mathrm{~g} \mathrm{~kg}^{-1}$ for cPOM-C, PPOM-C, cPOM-N and fPOM-N, respectively (Table 4). Considering POM-C as the sum of cPOM-C and PPOM-C, it represented about $15.6 \%$ of SOC, whereas POM-N (cPOM-N+fPOM-N) accounted for about $18.9 \%$ of SON. Total carbohydrates ranged from 2.09 to $3.41 \mathrm{~g}$ $\mathrm{kg}^{-1}$, averaging $2.62 \mathrm{~g} \mathrm{~kg}^{-1}$; CHs ranged from 0.22 to $0.44 \mathrm{~g} \mathrm{~kg}^{-1}$, with an average of $0.29 \mathrm{~g} \mathrm{~kg}^{-1}$. Total carbohydrates represented about $16.9 \%$ of SOC, and $\mathrm{CHs}$ about $1.8 \%$. Labile organic fractions showed a low $\mathrm{CV}$, from 7 to $28 \%$. 
Table 4. Nitrogen mineralization indices and labile soil organic fractions (mean \pm standard deviation) by site.

\begin{tabular}{|c|c|c|c|c|c|c|c|c|c|c|c|c|}
\hline \multirow[b]{3}{*}{ Sites } & \multicolumn{6}{|c|}{ Mineralization indices } & \multicolumn{6}{|c|}{ Labile organic matter fractions } \\
\hline & gNmin & Nan & Nhyd & $\mathrm{NO}_{3}-\mathrm{N}$ & $\mathrm{N}_{205}$ & $\mathrm{~N}_{260}$ & cPOM-C & fPOM-C & cPOM-N & fPOM-N & $\mathrm{CHt}$ & $\mathrm{CHs}$ \\
\hline & \multicolumn{4}{|c|}{$\left(\mathrm{mg} \mathrm{kg}^{-1}\right)$} & \multicolumn{2}{|c|}{ (absorbance) } & \multicolumn{6}{|c|}{$\left(\mathrm{g} \mathrm{kg}^{-1}\right)$} \\
\hline 1 & $47.4 \pm 11$ & $41.5 \pm 4.5$ & $67.2 \pm 2.8$ & $11.2 \pm 1.9$ & $1.58 \pm 0.03$ & $0.48 \pm 0.05$ & $1.54 \pm 0.13$ & $2.26 \pm 0.14$ & $0.126 \pm 0.01$ & $0.188 \pm 0.01$ & $3.39 \pm 0.23$ & $0.51 \pm 0.04$ \\
\hline 2 & $48.3 \pm 4.3$ & $42.5 \pm 11$ & $34.5 \pm 9.0$ & $23.3 \pm 7.1$ & $1.53 \pm 0.35$ & $0.38 \pm 0.06$ & $1.20 \pm 0.39$ & $0.76 \pm 0.14$ & $0.083 \pm 0.01$ & $0.104 \pm 0.03$ & $2.29 \pm 0.24$ & $0.27 \pm 0.02$ \\
\hline 3 & $60.6 \pm 16$ & $25.2 \pm 5.6$ & $10.7 \pm 2.1$ & $27.5 \pm 2.7$ & $2.28 \pm 0.35$ & $0.45 \pm 0.07$ & $0.83 \pm 0.13$ & $1.64 \pm 0.41$ & $0.096 \pm 0.01$ & $0.176 \pm 0.01$ & $2.62 \pm 0.06$ & $0.30 \pm 0.03$ \\
\hline 4 & $30.3 \pm 5.1$ & $32.2 \pm 1.4$ & $25.7 \pm 24$ & $14.0 \pm 3.5$ & $1.45 \pm 0.09$ & $0.39 \pm 0.07$ & $0.73 \pm 0.06$ & $1.15 \pm 0.81$ & $0.122 \pm 0.01$ & $0.134 \pm 0.02$ & $1.97 \pm 0.23$ & $0.30 \pm 0.01$ \\
\hline 5 & $62.7 \pm 6.3$ & $61.1 \pm 3.5$ & $34.1 \pm 6.6$ & $17.7 \pm 8.5$ & $1.71 \pm 0.08$ & $0.51 \pm 0.09$ & $1.34 \pm 0.47$ & $1.83 \pm 0.93$ & $0.106 \pm 0.02$ & $0.179 \pm 0.01$ & $2.29 \pm 0.23$ & $0.39 \pm 0.03$ \\
\hline 6 & $67.1 \pm 11$ & $99.4 \pm 4.8$ & $36.9 \pm 13$ & $18.2 \pm 4.9$ & $1.58 \pm 0.03$ & $0.48 \pm 0.06$ & $1.65 \pm 0.25$ & $0.95 \pm 0.08$ & $0.152 \pm 0.04$ & $0.161 \pm 0.01$ & $3.17 \pm 0.35$ & $0.41 \pm 0.05$ \\
\hline 7 & $88.4 \pm 6.0$ & $27.1 \pm 0.8$ & $25.2 \pm 4.8$ & $20.3 \pm 9.8$ & $1.85 \pm 0.24$ & $0.44 \pm 0.03$ & $0.62 \pm 0.12$ & $0.55 \pm 0.03$ & $0.052 \pm 0.01$ & $0.081 \pm 0.004$ & $2.18 \pm 0.28$ & $0.27 \pm 0.01$ \\
\hline 8 & $116.3 \pm 15$ & $70.9 \pm 4.5$ & $47.1 \pm 7.7$ & $23.1 \pm 7.0$ & $2.29 \pm 0.41$ & $0.38 \pm 0.04$ & $1.01 \pm 0.17$ & $2.40 \pm 0.89$ & $0.102 \pm 0.01$ & $0.256 \pm 0.01$ & $4.28 \pm 0.56$ & $0.75 \pm 0.07$ \\
\hline 9 & $57.1 \pm 16$ & $74.2 \pm 5.0$ & $46.2 \pm 6.4$ & $25.2 \pm 0.7$ & $2.28 \pm 0.35$ & $0.45 \pm 0.07$ & $0.70 \pm 0.08$ & $0.95 \pm 0.06$ & $0.087 \pm 0.03$ & $0.166 \pm 0.01$ & $2.22 \pm 0.43$ & $0.38 \pm 0.01$ \\
\hline mean & 64.2 & 52.7 & 36.4 & 20.1 & 1.84 & 0.44 & 1.07 & 1.39 & 0.103 & 0.161 & 2.72 & 0.40 \\
\hline $\mathrm{CV}^{\mathrm{a}}$ & 40 & 47 & 49 & 35 & 22 & 16 & 19 & 28 & 15 & 7 & 11 & 8 \\
\hline
\end{tabular}

${ }^{\mathrm{a}} \mathrm{CV}$, coefficient of variation. $\mathrm{gNmin}$, Net $\mathrm{N}$ mineralization $\left(\mathrm{mg} \mathrm{kg}^{-1}\right)$; Nan, anaerobic $\mathrm{N}\left(\mathrm{mg} \mathrm{kg}^{-1}\right)$; Nhyd, chemical labile $\mathrm{N}$ minus initial $\mathrm{N}$ in ammonium form ( $\left.\mathrm{mg} \mathrm{kg}^{-1}\right) ; \mathrm{N}^{-\mathrm{NO}_{3}}$, nitrate $\mathrm{N}\left(\mathrm{mg} \mathrm{kg}^{-1}\right) ; \mathrm{N}_{205}, \mathrm{~N}$ determined by spectrometer at $205 \mathrm{~nm}$ (absorbance); $\mathrm{N}_{260}, \mathrm{~N}$ determined by spectrometer at $260 \mathrm{~nm}$ (absorbance); cPOM-C, coarse particulate organic carbon ( $\mathrm{g} \mathrm{kg}^{1}$ ); cPOM-N, coarse particulate organic nitrogen $\left(\mathrm{g} \mathrm{kg}^{-1}\right)$; POM-C, fine particulate organic carbon $\left(\mathrm{g} \mathrm{kg}^{-1}\right)$; fPOM-N, fine particulate organic nitrogen $\left(\mathrm{g} \mathrm{kg}^{-1}\right)$; $\mathrm{CHt}$, total carbohydrates $\left(\mathrm{g} \mathrm{kg}^{-1}\right)$; $\mathrm{CHs}$, soluble carbohydrates $\left(\mathrm{g} \mathrm{kg}^{-1}\right)$.

3.4.. Relationships among $N_{0}$ and $N_{\text {okf }}$ with $\mathrm{N}$-mineralization indices, labile organic fractions and soil properties

On the basis of Pearson's correlations (Table 5), high positive and significant relationships were detected between $\mathrm{N}_{0}$ and $\mathrm{N}_{0 \mathrm{kf}}$ with some labile organic fractions $(\mathrm{r}>0.64)$, i.e. $\mathrm{C}$ and $\mathrm{N}$ in fine $\mathrm{POM}$ fractions ( $\mathrm{fPOM}-\mathrm{C}$ and $\mathrm{PPOM}-\mathrm{N}$ ) and soil carbohydrates ( $\mathrm{CHt}$ and $\mathrm{CHs}$ ). Also, some significant correlations were observed between $\mathrm{N}_{0}$ and $\mathrm{N}_{0 \mathrm{kf}}$ with $\mathrm{N}$-mineralization indices, but with a low correlation coefficient $(r<0.53)$. The $\mathrm{N}_{0 \mathrm{kf}}$ showed positive and significant relationships with
gNmin, SOC, SON and its fractions. As to the indices determined by UV, $\mathrm{N}_{205}$ showed significant relations with $\mathrm{N}_{0}$ and $\mathrm{N}_{0 \mathrm{kf}}$ with a low correlation coefficient $(\mathrm{r}<0.50)$.

Considering soil properties, close correlations were found between $\mathrm{N}_{0}$ at a variable and at a fixed constant rate with most soil chemical and physical properties, especially with texture (sand and silt content) (Table 5). Regarding soil texture, high and negative correlations were found between $\mathrm{N}_{0}$ and $\mathrm{N}_{\text {okf }}$ with sand, and positive with silt, which shows that these soils have a low clay content, except for soil 8 (Table 2). 
Table 5. Pearson's correlation of potentially mineralizable $\mathrm{N}$ at a variable and at a fixed rate with $\mathrm{N}$ mineralization indices, labile organic matter fractions and soil properties.

\begin{tabular}{|c|c|c|c|c|}
\hline & \multicolumn{2}{|c|}{$\mathrm{N}_{0}$} & \multicolumn{2}{|c|}{$\mathrm{N}_{0 \mathrm{kf}}$} \\
\hline & $\mathrm{r}$ & p-value & $\mathrm{r}$ & $\mathrm{p}$-value \\
\hline gNmin & 0.53 & $* *$ & 0.50 & $* *$ \\
\hline Nan & 0.39 & * & 0.25 & $n s$ \\
\hline Nhyd & 0.40 & $*$ & 0.31 & $n s$ \\
\hline $\mathrm{NO}_{3}-\mathrm{N}$ & 0.21 & $n s$ & 0.19 & $n s$ \\
\hline $\mathrm{N}_{205}$ & 0.43 & $*$ & 0.47 & * \\
\hline $\mathrm{N}_{260}$ & 0.04 & $n s$ & 0.11 & $n s$ \\
\hline cPOM-C & 0.33 & $n s$ & 0.30 & $n s$ \\
\hline fPOM-C & 0.64 & $* * *$ & 0.68 & $* * *$ \\
\hline cPOM-N & 0.17 & $n s$ & 0.13 & $n s$ \\
\hline fPOM-N & 0.83 & $* * *$ & 0.84 & $* * *$ \\
\hline $\mathrm{CHt}$ & 0.72 & $* * *$ & 0.72 & $* * *$ \\
\hline $\mathrm{CHs}$ & 0.71 & $* * *$ & 0.69 & $* * *$ \\
\hline SOC & 0.71 & $* * *$ & 0.67 & $* *$ \\
\hline SON & 0.75 & $* * *$ & 0.68 & $* * *$ \\
\hline $\mathrm{pH}$ & 0.71 & $* * *$ & 0.64 & $* * * *$ \\
\hline $\mathrm{Pe}$ & -0.50 & $*$ & -0.48 & $*$ \\
\hline $\mathrm{C}: \mathrm{N}$ & 0.25 & $n s$ & 0.28 & $n s$ \\
\hline $\mathrm{BD}$ & -0.75 & $* * *$ & -0.61 & $* * *$ \\
\hline sand & -0.89 & $* * *$ & -0.92 & $* * *$ \\
\hline silt & 0.85 & $* * *$ & 0.89 & $* * *$ \\
\hline clay & 0.39 & $*$ & 0.51 & $* *$ \\
\hline
\end{tabular}

$\mathrm{r}$, correlation coefficient; $\mathrm{N}_{0}$, aerobic potentially mineralizable $\mathrm{N} ; \mathrm{N}_{0 \mathrm{kf}}$, potentially mineralizable $\mathrm{N}$ at a fixed constant rate $(k)$ $\left(0.054\right.$ week $\left.^{-1}\right)$. See abreviations in Table 2 and $4 . * * *, * * *$, significant correlation at $0.05 ; 0.01,0.001$ probability levels, respectively. $n s$, no significant.

3.5. Grouping N-mineralization indices, labile organic fractions and soil properties

Considering the significant highly correlated variables for $\mathrm{N}_{0}$ and $\mathrm{N}_{0 \mathrm{kf}}$ (Table 5), we conducted a PCA (Table 6). In $\mathrm{N}_{0}$, the PCA showed eigenvalues greater than 1 in the first four PCs, which accounted for $82 \%$ of the total variance. The PC1 explained $51 \%$ of the variance, and the loading was positive with SOM fractions (SOC, SON, CHs, fPOM-N) and negative with sand (Table 6). PC2 explained $14 \%$ of the variance, in which clay content showed positive associations. The third PC accounted for $10 \%$ and it had a high and positive loading for Nan, whereas the fourth PC explained 7\%, with a high and negative loading for cPOM-N. In $\mathrm{N}_{\text {okf }}$, the PCA showed eigenvalues greater than 1 in the first three PCs. The PC1 explained $71 \%$ of the variance and had the same variables for $\mathrm{N}_{0}$ (Table 6). The PC2 accounted for $15 \%$ of the variance, in which clay content showed positive associations as in PCA for $\mathrm{N}_{0}$. The third PC represented $9 \%$ and had high and positive loading for gNmin. In fact, it can be observed that the first three PCs are divided in terms of their association with the size of SOM fractions (PC1), with soil texture (PC2) and with the N lability (PC3). 
Table 6. Results of principal component analysis for $\mathrm{N}_{0}$ and $\mathrm{N}_{\text {okf }}$

\begin{tabular}{|c|c|c|c|c|c|c|c|}
\hline & \multicolumn{4}{|c|}{$\mathrm{N}_{0}$} & \multicolumn{3}{|c|}{$\mathrm{N}_{\mathrm{okf}}$} \\
\hline & PC1 & PC2 & $\mathrm{PC} 3$ & PC4 & PC1 & PC2 & PC3 \\
\hline Eigenvalue & 8.13 & 2.17 & 1.55 & 1.16 & 7.80 & 2.09 & 1.30 \\
\hline Proportion of variance & 0.51 & 0.14 & 0.10 & 0.07 & 0.56 & 0.15 & 0.09 \\
\hline Total variance & 0.51 & 0.65 & 0.75 & 0.82 & 0.56 & 0.71 & 0.80 \\
\hline Variable & \multicolumn{4}{|c|}{ Eigenvectors } & \multicolumn{3}{|c|}{ Eigenvectors } \\
\hline gNmin & 0.21 & 0.25 & -0.32 & 0.30 & 0.22 & 0.24 & 0.46 \\
\hline Nan & 0.15 & 0.14 & 0.48 & 0.42 & - & - & - \\
\hline Nhyd & 0.16 & -0.18 & 0.37 & -0.04 & - & - & - \\
\hline $\mathrm{N}_{205}$ & 0.16 & 0.43 & -0.35 & -0.05 & 0.17 & 0.45 & 0.33 \\
\hline cPOM-C & - & - & - & - & - & - & - \\
\hline fPOM-C & 0.25 & -0.11 & 0.01 & -0.47 & 0.26 & -0.07 & -0.26 \\
\hline fPOM-N & 0.33 & 0.05 & 0.13 & -0.15 & 0.33 & 0.05 & -0.23 \\
\hline $\mathrm{CHt}$ & 0.28 & 0.003 & 0.28 & -0.07 & 0.28 & -0.01 & -0.35 \\
\hline $\mathrm{CHs}$ & 0.30 & -0.09 & 0.20 & -0.05 & 0.31 & -0.08 & -0.24 \\
\hline SOC & 0.30 & 0.01 & -0.16 & 0.29 & 0.31 & -0.003 & 0.26 \\
\hline SON & 0.31 & -0.04 & -0.07 & 0.31 & 0.32 & -0.06 & 0.19 \\
\hline $\mathrm{Pe}$ & -0.22 & -0.30 & -0.24 & -0.09 & -0.22 & -0.29 & 0.21 \\
\hline $\mathrm{pH}$ & 0.23 & -0.40 & -0.27 & 0.14 & 0.23 & -0.41 & 0.30 \\
\hline Sand & -0.31 & -0.07 & 0.19 & 0.19 & -0.32 & -0.07 & -0.06 \\
\hline Silt & 0.29 & -0.19 & -0.27 & -0.02 & 0.29 & -0.21 & 0.20 \\
\hline Clay & 0.15 & 0.49 & 0.08 & -0.38 & 0.15 & 0.53 & -0.24 \\
\hline $\mathrm{BD}$ & -0.23 & 0.37 & -0.05 & 0.16 & -0.24 & 0.38 & 0.19 \\
\hline
\end{tabular}

Bold letter indicates the variables with higher loadings. $\mathrm{N}_{0}$, aerobic potentially mineralizable $\mathrm{N} ; \mathrm{N}_{0 \mathrm{k}}$, potentially mineralizable $\mathrm{N}$ at a fixed constant rate $\left(0.054\right.$ week $\left.^{-1}\right)$. See abbreviations in Table 2 and 4.

3.6. Prediction of $N$ mineralizable using multivariate analysis

Taking into account the new variables generated by the PCA (Table 6), the MR using stepwise meth- od selected one PC for $\mathrm{N}_{0}$ at a variable and at a fixed constant rate (Table 7). High $\mathrm{R}^{2}$ values were found for predicting $\mathrm{N}_{0}$ (adj $\mathrm{R}^{2}=0.84$ ) and $\mathrm{N}_{0 \mathrm{kf}}$ (adj $\mathrm{R}^{2}=0.83$ ).

Table 7. Prediction of potentially mineralizable nitrogen at a variable and at a fixed constant rate using principal component as regressor variable.

\begin{tabular}{|c|c|c|c|c|c|c|c|c|}
\hline $\begin{array}{c}\text { Dependent } \\
\text { variable }\end{array}$ & $\begin{array}{c}\text { Regressor } \\
\text { variable }\end{array}$ & $\begin{array}{l}\text { Estimated } \\
\text { parameter }\end{array}$ & $\begin{array}{c}\text { Standard } \\
\text { error }\end{array}$ & P-value & \multicolumn{2}{|c|}{$\begin{array}{l}\text { 95\% Confidence } \\
\text { limits }\end{array}$} & $\mathrm{R}^{2}$ & $\begin{array}{l}\text { Adj } \\
\mathrm{R}^{2}\end{array}$ \\
\hline \multirow[t]{2}{*}{$\mathrm{N}_{0}$} & Intercept & 117.5 & 4.05 & $<0.0001$ & 109.2 & 125.9 & 0.85 & 0.84 \\
\hline & PC1 N 0 & 17.1 & 1.5 & $<0.0001$ & 14.8 & 20.1 & & \\
\hline \multirow[t]{2}{*}{$\mathrm{N}_{0 \mathrm{kf}}$} & Intercept & 97.9 & 3.4 & $<0.0001$ & 90.9 & 104.9 & 0.84 & 0.83 \\
\hline & PC1 $\mathrm{N}_{0 \mathrm{kf}}$ & 14.5 & 1.3 & $<0.0001$ & 11.8 & 17.1 & & \\
\hline
\end{tabular}

All prediction equations are constructed in the form $\mathrm{y}=\beta 0+\mathrm{x} 1 \beta 1$, where $\beta 0$ is the intercept and $\beta 1$ is the parameter estimates and $\mathrm{x} 1$ is the new variable generated by PCA. $\mathrm{N}_{0}$, aerobic potentially mineralizable $\mathrm{N} ; \mathrm{N}_{0 \mathrm{kf}}$, potentially mineralizable $\mathrm{N}$ at a fixed constant rate $(k)\left(0.054\right.$ week $\left.^{-1}\right)$. 


\section{Discussion}

\subsection{Potential N mineralization, soil $N$-mineralization indices and labile SOM fractions}

Values of $\mathrm{N}_{0}$ were similar to those reported by other authors (Sharifi et al., 2007; Nyiraneza et al., 2011). Using a fixed $k\left(0.054 \mathrm{wk}^{-1}\right)$ to determine $\mathrm{N}_{0 \mathrm{kf}}$ produced slightly lower values compared with $\mathrm{N}_{0}$. Although use of the fixed $k$ approach reduced the $\mathrm{CV}$ of potential $\mathrm{N}$ mineralization in other studies (Sharifi et al., 2007), in the present study the $\mathrm{CV}$ of $\mathrm{N}_{0}$ and $\mathrm{N}_{0 \mathrm{kf}}$ was similar.

The mean value of $k$ was closer to the 0.054 week $^{-1}$ reported by Stanford and Smith (1972); this difference among soils was also observed by other authors (Sharifi et al., 2007). The $k$ values were greater in sandy soils than in loam soils. Schomberg et al. (2009) found higher $k$ values in medium- to coarse-textured soils than in fine-textured soils. This may have occurred because SOM is physically less protected by clays $(\mathrm{Ny}-$ iraneza et al., 2011) and by the higher labile fraction in medium- to coarse-textured soils (Martínez and Galantini, 2017). The high relationship $\left(\mathrm{R}^{2}=0.94\right)$ between $\mathrm{N}_{0}$ and $\mathrm{N}_{0 \mathrm{kf}}$ showed that potential mineralization can be measured more easily by standardizing $k$ at a fixed value, despite contrasting $k$ values observed in Table 3 and the differences in soil properties. In addition, other authors (Schomberg et al., 2009; Dessureault-Rompré et al., 2010) stated that it is difficult to identify a compositional factor that is predictive of $k$.

The mean gNmin value was twice as much as that reported by Schomberg et al. (2009), who obtained $21 \mathrm{mg} \mathrm{kg}^{-1}$ in different soils in Canada and the USA under contrasting managements. However, they fit in the range studied by Curtin and Wen (1999) for soils under different managements in Canada and they coincide with studies by Dessureault-Rompré et al. (2010), who studied several soils from four eco-zones in the same country. The Nan values were within the range reported by other authors (Sharifi et al., 2007; Schomberg et al., 2009). The Nhyd values were similar to those obtained by Gianello and Bremner (1986) for 33 tropical soils, but higher than those (2.3-16.1 $\mathrm{mg} \mathrm{kg}^{-1}$ ) reported by Schomberg et al. (2009). Ranges for $\mathrm{N}_{205}$ and $\mathrm{N}_{260}$ resembled those reported by Sharifi et al. (2007) in soils at 0-15 cm under different crops in contrasting climate areas. On the other hand, high variability (relatively high $\mathrm{CV}$ ) in mineralization indices - except for $\mathrm{N}_{205}$ and $\mathrm{N}_{260}$ - highlighted the differences among soil parameters in these Mollisols. Also, Sharifi et al. (2007) reported low CV for $\mathrm{N}_{205}$ and $\mathrm{N}_{260}$ when comparing mineralization methods in various soils.

In contrast, differences across sites are very few in terms of labile organic fractions because of a low CV. They also showed that the labile organic fractions that make up POM represent a small part of SOM.

\subsection{Relationships among $N_{0}, N_{0 k p} N$-mineralization indices and labile organic fractions and soil properties}

On the basis of Pearson's correlations (Table 5), low significant relationships were detected between $\mathrm{N}_{0}$ and Nan $(\mathrm{P}<0.05)$, as reported by other authors (Sharifi et al., 2007). The positive relationship between $\mathrm{N}_{0}$ and Nhyd was similar to the one found by Curtin and Wen (1999) in cultivated soils of Canada, and they reported an $\mathrm{R}^{2}=0.13$ for the $0-15 \mathrm{~cm}$ depth. Correlation between $\mathrm{N}_{0}$ and gNmin was similar to that observed by Nyiraneza et al. (2011), who reported an $\mathrm{r}$ of 0.63 in humid areas under conventional tillage (CT) at the 0-7.5 cm depth. The $\mathrm{N}_{\text {okf }}$ showed positive significant relations with gNmin, $\mathrm{SOC}, \mathrm{SON}$ and its fractions. As to the indices determined by $\mathrm{UV}, \mathrm{N}_{205}$ showed significant relations with $\mathrm{N}_{0}$ and $\mathrm{N}_{\text {okf }}$. The most important variables related to $\mathrm{N}_{0}$ and $\mathrm{N}_{\text {okf }}$ were the labile organic fractions $(\mathrm{r}>0.64)$, i.e. $\mathrm{C}$ and $\mathrm{N}$ in fine particulate 
organic fractions (fPOM-C and fPOM-N) and soil CH (CHt and $\mathrm{CHs}$ ). With respect to this latter, it is important to emphasize it capacity in providing energy to soil microorganisms, given that $\mathrm{CH}$ content is enhanced under NT (Duval et al., 2013). In general, labile organic matter (e.g. fPOM-C; fPOM-N; CHt and $\mathrm{CHs}$ ) tended to be more strongly related to $\mathrm{N}_{0}$ and $\mathrm{N}_{0 \mathrm{kf}}$ than to $\mathrm{N}$ mineralization indices.

\subsection{Prediction of $N$ mineralizable using multivariate analysis}

For both predictions the results indicate that $\mathrm{N}$ mineralization indices are not relevant as were the organic fractions and soil texture. The results showed that both total and labile organic fractions and sand content are in the same PC. The best prediction was given by SOC, SON, CHs, fPOM-N and sand content. The importance of these SOM fractions for $\mathrm{N}$ mineralization has been further corroborated by numerous studies evaluating the predictive value of single soil organic fraction for the prediction of mineralizable $\mathrm{N}$ (Ros et al., 2011; Martínez et al., 2017). Also, these organic fractions are known to be highly labile (Duval et al., 2013; Duval et al., 2016) and they can release nutrients in the short term (Galantini and Landriscini, 2007). Other authors (Ros et al., 2011) had reported close relationships between $\mathrm{CHs}$ and mineralizable N. Duval et al. (2013) suggested that CHs are mainly of microbial origin, considering them as highly labile component as energy source for soil microorganisms. In addition, Haynes (2005) stated that hot water-extracted organic matter was largely composed of polysaccharides and $\mathrm{N}$-containing compounds as amino-N and amides. Therefore, $\mathrm{CHs}$ and fPOM-N could function as a source of $\mathrm{N}$ within the mineralization in these Mollisols. Hence, both labile organic fractions could be used as $\mathrm{N}$ mineralization indices, especially when assessing soil quality in these Mollisols characterized by low POM input from crop residues. Several authors (Puget et al., 1999; Duval et al., 2013; Duval et al., 2016) had already discussed about the high sensitivity of these labile fractions under different land managements.

Regarding soil texture, Martínez and Galantini (2017) showed that $\mathrm{N}$ release was faster in sandy soils than in clayey soils because the physical protection of SOM was lower. In this study, sand regulated the levels of SOM and its labile fractions; i.e. soils with a higher sand content have lower levels of SOC, SON and its labile fractions, resulting in lower $\mathrm{N}_{0}$ and $\mathrm{N}_{\text {okf }}$. This could be verified by highly significant and negative correlations between sand with SOC $(r=-0.67)$, SON $(r=-0.67)$, CHs $(r=-0.63)$ and fPOM-N $(r=-0.80)$ (data not shown). These results suggest that $\mathrm{N}$ mineralization in these soils was related to the size of SOM and its fractions rather than to its quality. These results were similar to the findings of other studies in contrasting soils (Ros et al., 2011).

Results of the current study suggest that potential $\mathrm{N}$ mineralization -considering a variable and a fixed constant rate - may be mainly controlled by the variables related to the size of SOM and some labile organic fractions related to the $\mathrm{C}$ - and $\mathrm{N}$ cycling (fPOM-N and $\mathrm{CHs}$ ), despite the low POM input from residues in these soils. This study helps to better understand the complex dynamics of soil $\mathrm{N}$ mineralization in these Mollisols. However, the $\mathrm{N}$ mineralization is a dynamic process that can vary during the crop growing season as a result of the interaction between labile organic fractions and water availability, which are highly variable factors in these areas. The results of this study highlight about the factors that controls the size and kinetics of potential $\mathrm{N}$ mineralizable to better predict growing season $\mathrm{N}$ mineralization. Hence, the labile pools of soil organic $\mathrm{N}$ should be studied in further detail over the crop growing season. 


\section{Conclusions}

The results of this study concluded that in Mollisols under these conditions no single $\mathrm{N}$ mineralization index, labile organic fraction or soil property can accurately predict $\mathrm{N}_{0}$ at a variable or at a fixed constant rate. In spite of this result, it is important to emphasize that soil sand content is the most influential predictor of potential $\mathrm{N}$ mineralization. Furthermore, a constant rate value $\left(0.054\right.$ week $\left.^{-1}\right)$ can be used to estimate the $\mathrm{N}$ to be mineralized during the crop growing season with similar accuracy. The multivariate analysis such as PCA allowed combination of mineralization indices, labile organic fractions and soil variables into groups relevant enough for determining the mineralizable $\mathrm{N}$ pool. Also, it improved the prediction of $\mathrm{N}_{0}$ and $\mathrm{N}_{0 \mathrm{kf}}$ by using PC as regressor and it allowed elimination of the multicollinearity generated from MR models using high correlated variables. The mineralization $\mathrm{N}$ pool may be controlled mainly by the variables related to the size of SOM and some fractions in these Mollisols, such as SOC, SON, CHs and fPOM-N. These latter labile organic fractions would be expected to be more sensitive to short-term changes in potential $\mathrm{N}$ mineralization due to changes in soil management practices and history. However, its effectiveness for other soils and tillage conditions has to be evaluated.

\section{Acknowledgements}

The authors wish to thank farmers from AAPRESID (Argentine Association of farmers under No-tillage), Regional Bahía Blanca, and to Profertil S.A.

\section{References}

Álvarez, R., Lavado, R.S. 1998. Climate, organic matter and clay content relationships in the Pampa and Chaco soils, Argentina. Geoderma. 83, 127141.
Blake, G.R., Hartge, K.H. 1986. Bulk density. In: A. Klute (ed). Methods of soil analysis. American Society of Agronomy and Soil Science Society of America, Madison, WI, pp: 363-375.

Bray, R., Kurtz, L. 1945. Determination of total, organic and available forms of phosphorus in soil. Soil Sci. 59, 39-45.

Bremner, J.M. 1996. Nitrogen-Total. In: D.L. Sparks (ed). Methods of soil analysis. Chemical Methods. American Society of Agronomy and Soil Science Society of America, Madison, WI, pp: 1085-1121.

Curtin, D., Wen, G. 1999. Organic matter fractions contributing to soil nitrogen mineralization potential. Soil Sci. Soc. Am. J. 63, 410-415.

Dessureault-Rompré, J., Zebarth, B.J., Georgallas, A., Burton, D.L., Grant, C.A., Drury, C.F. 2010. Temperature dependence of soil nitrogen mineralization rate: Comparison of mathematical models, reference temperatures and origin of the soils. Geoderma. 157, 97-108.

Di Rienzo, J.A., Casanoves, F., Balzarini, M.G., Gonzalez, L., Tablada, M., Robledo, C.W. 2013. InfoStat versión 2013. Grupo InfoStat, FCA, Universidad Nacional de Córdoba, Argentina.

Dubois, M., Gilles, K., Hamilton, J., Rebers, P., Smith, R. 1956. Colorimetric method for determination of sugars and related substances. Anal. Chem. 28, 350-356.

Duval, M.E., Galantini, J.A., Iglesias, J.O., Canelo, S., Martínez, J.M., Wall, L. 2013. Analysis of organic fractions as indicators of soil quality under natural and cultivated systems. Soil Till. Res. 131, 11-19.

Duval, M.E., Galantini, J.A., Martínez, J.M., López, F.M., Wall, L.G. 2016. Sensitivity of different soil quality indicators to assess sustainable land management: Influence of site features and seasonality. Soil Till. Res. 159, 9-22. 
Galantini, J.A., Duval, M.E., Martínez, J.M., Mora, V., Baigorri, R., García-Mina, J.M. 2016. Quality and Quantity of Organic Fractions as Affected by Soil Depth in an Argiudoll under Till and No-till Systems. Int. J. Plant Soil Sci. 10, 1-12.

Galantini, J.A., Landriscini, M.R. 2007. Equilibrio y dinámica de las fracciones orgánicas del suelo: Relación con la fertilidad del suelo y la sustentabilidad del sistema. In: A. Thuar, F. Cassán, C. Olmedo (eds). De la Biología del Suelo a la Agricultura (In Spanish). Universidad Nacional de Río Cuarto, Río Cuarto (Argentina), pp: 229-245.

Gee, G.W., Bauder, J.W. 1986. Particle-size analysis. In: A. Klute (ed). Methods of Soil Analysis. Part 1: Physical and Mineralogical Methods. American Society of Agronomy and Soil Science Society of America, Madison, WI, pp: 383-411.

Gianello, C., Bremner, J.M. 1986. Simple chemical method of assessing potentially available organic nitrogen in soil. Commun. Soil Sci. Plant Anal. 17, 195-214.

Griffin, T.S., Honeycutt, C.W., Albrecht, S.L., Sistani, K.R., Torbert, H.A., Wienhold, B.J., Woodbury, B.L., Hubbard, R.K., Powell, J.M. 2008. Nationally-coordinated evaluation of soil nitrogen mineralization rate using a standardized aerobic incubation protocol. Commun. Soil Sci. Plant Anal. 39, 257-268.

Haynes, R.J. 2005. Labile organic matter fractions as central components of the quality of agricultural soils: An overview. Adv. Agron. 85, 221-268.

Klute, A. 1986. Water retention: Laboratory methods. In: A. Klute (ed). Methods of soil analysis. Part 1. American Society of Agronomy, Madison, WI, pp: 597-618.

Li, P., Zhang, T., Wang, X., Yu, D. 2013. Development of biological soil quality indicator system for subtropical China. Soil Till. Res. 126, 112-118.
MacLean, A.A. 1964. Measurement of nitrogen supplying-power of soils by extraction with sodium bicarbonate. Nature 203, 307-1308.

Martínez, J.M., Galantini, J.A. 2017. A Rapid Chemical Method for Estimating Potentially Mineralizable and Particulate Organic Nitrogen in Mollisols. Commun. Soil Sci. Plant. Anal. 48, 113-126.

Martínez, J.M., Galantini, J.A., Duval, M.E., López, F.M. 2017. Tillage effects on labile pools of soil organic nitrogen in a semi-humid climate of Argentina: A long-term field study. Soil Till. Res. 169, 71-80.

Martínez-Lagos, J., Salazar, F., Alfaro, M., Rosas, M., Macías, F. 2015. Nitrogen mineralization in a silandic andosol fertilized with dairy slurry and urea. J. Soil Sci. Plant Nutr. 15, 60-75.

Moya, H., Verdejo, J., Yáñez, C., Álvaro, J.E., Sauvé, S., Neaman, A. 2016. Nitrification and nitrogen mineralization in agricultural soils contaminated by copper mining activities in Central Chile. J. Soil Sci. Plant Nutr. 17, 205-213.

Mulvaney, R.L. 1996. Nitrogen- Inorganic forms. In: D. L. Sparks et al. (eds). Methods of Soil Analysis. Chemical Methods. Soil Science Society of America, Madison, WI, pp: 1123-1184.

Nyiraneza, J., Zebarth, B. J., Ziadi, N., Burton, D. L., Drury, C. F., Bittman, S., Grant, C. A. 2011. Prediction of soil nitrogen supply in corn production using soil chemical and biological indices. Soil Sci. Soc. Am. J. 76, 925-935.

Puget, P., Angers, D.A., Chenu, C. 1999. Nature of carbohydrates associated with water-stable aggregates of two cultivated soils. Soil Biol. Biochem. $31,55-63$.

Ramírez, M.V., Rubilar R.A., Montes, C., Stape, J.L., Fox, T.R., Lee-Allen, H. 2016. Nitrogen availability and mineralization in Pinus radiate stands fertilized mid-rotation at three contrasting sites. J. Soil Sci. Plant Nutr. 16, 118-136. 
Ros, G.H., Hanegraaf, M.C., Hoffland, E., van Riemsdijk, W.H. 2011. Predicting soil N mineralization: Relevance of organic matter fractions and soil properties. Soil Biol. Biochem. 43, 1714-1722.

Satorre, E.H., Slafer, G.A. 1999. Wheat production systems of the Pampas In: E. M. Satorre et al. (eds). Wheat. Ecology and Physiology of Yield Determination. The Haworth Press Inc., New York, NY, pp: 333-348.

Schomberg, H.H., Wietholter, S., Griffin, T.S., Reeves, D.W., Cabrera, M.L., Fisher, D.S., Endale, D.M., Novak, J.M., Balkcom, K.S., Raper, R.L., Kitchen, N.R., Locke, M.A., Potter, K.N., Schwartz, R.C., Truman, C.C., Tyler, D.D. 2009. Assessing indices for predicting potential nitrogen mineralization in soils under different management systems. Soil Sci. Soc. Am. J. 73, 1575-1586.
Sharifi, M., Zebarth, B.J., Burton, D.L., Grant, C.A., Cooper J.M. 2007. Evaluation of some indices of potentially mineralizable nitrogen in soil. Soil Sci. Soc. Am. J. 71, 1233-1239.

Shukla, M.K., Lal, R., Ebinger, M. 2004. Principal component analysis for predicting corn biomass and grain yields. Soil Sci.169, 215-224.

Soil Survey Staff. 2010. Keys to Soil Taxonomy, $11^{\text {th }}$ ed. USDA-Natural Resources 22 Conservation Service, Washington, DC.

St. Luce, M., Whalen, J.K., Ziadi, N., Zebarth, B.J. 2011. Nitrogen dynamics and indices to predict soil nitrogen supply in humid temperate soils. Adv. Agron. 112, 55-102.

Stanford, G., Smith, S. 1972. Nitrogen mineralization potentials of soils. Soil Sci. Soc. Am. Proc. 36, 465-472. 